\title{
Multiple clonal Ig/TCR products: implications for interpretation of clonality findings
}

\author{
Anton W. Langerak • Jacques J. M. van Dongen
}

Received: 30 June 2011 / Accepted: 23 November 2011 / Published online: 10 December 2011

(C) Springer-Verlag 2011

\begin{abstract}
Clonality assessment via analysis of immunoglobulin (Ig) and T cell receptor (TCR) gene rearrangements has become an important and valuable adjunct in the diagnostic process of suspect lymphoproliferations. One of the major issues in correct interpretation of clonality testing results appears to be the occurrence of multiple clonal PCR products. The presence of two different PCR products could reflect biclonality but can often more easily be attributed to the occurrence of biallelic rearrangements in a single clone. Furthermore, due to the specific configuration of the $I G K$ and TCRB loci, multiple rearrangements can occur on one allele, resulting in the possibility that up to four PCR products could be compatible with a single clone. Finally, $>2$ clonal Ig/TCR products $(>4$ for $I G K$ and $T C R B$ ) could reflect biclonality, oligoclonality, or even pseudoclonality. It is not always easy to distinguish between those options, but the use of duplicates will be helpful to determine reproducibility and relevance of the detected clonal PCR products. In conclusion, straightforward interpretation of clonality testing results can be hampered by the occurrence of multiple clonal products. Only careful consideration of immunobiological and technical explanations will prevent incorrect interpretation in such cases.
\end{abstract}

Keywords Clonality $\cdot I G K \cdot T C R B \cdot$ Biallelic $\cdot$ Biclonal

\footnotetext{
A. W. Langerak $(\bowtie) \cdot J$ J. J. M. van Dongen

Department of Immunology, Erasmus MC, University Medical Center Rotterdam,

Dr. Molewaterplein 50,

3015 GE, Rotterdam, The Netherlands

e-mail: a.langerak@erasmusmc.nl
}

\section{Introduction}

Clonality assessment via analysis of immunoglobulin (Ig) and $\mathrm{T}$ cell receptor (TCR) gene rearrangements has become an important and valuable adjunct in the diagnostic process of suspect lymphoproliferations. This holds for histopathologically suspect lymphoid lesions in tissues (lymph nodes, spleen, skin, and gastrointestinal tract) but is similarly true in case of a lymphocytosis or suspect lymphocyte population in bone marrow, peripheral blood, or other body fluids (such as spinal fluid). Initially, such clonality testings could only be done by means of Southern blot analysis [10, 11]. Meanwhile, multiple protocols and primer sets for PCRbased clonality assessment have been developed, initially mainly focusing on two targets: IGH (Ig heavy chain locus) for B cell clonality and TCR $G$ (TCR gamma locus) for T cell clonality. These two targets were mainly chosen because of their broad applicability and because of the limited number of primers required. At the end of the 90s of the previous century, a European BIOMED-2 consortium started to redesign primers and optimize PCR protocols for Ig/TCR clonality testing [12]. This has resulted in standardized multiplex PCR protocols for $I G H$ and $T C R G$ analysis, which showed very good performance when evaluated in large series of WHOdefined lymphoma and leukemia entities $[1,3,6]$. Importantly, the BIOMED-2 consortium (now called EuroClonality) has also developed multiplex PCR protocols for alternative targets for B cell (IGK and IGL, Ig kappa and lambda light chain locus, respectively) and T cell (TCRB and TCRD, TCR beta and delta, respectively) clonality testing. Especially, the $I G K$ and TCRB gene rearrangement assays have proven to be highly informative. Hence, these targets could serve as alternatives for $I G H$ and $T C R G$, respectively, but also have important complementary value and unprecedented performance when used in combination with $I G H$ and $T C R G[1,3]$. 
Along with the technical standardization of the multiplex PCR protocols and their commercial availability in kit format, these tests have now found their way to routine clonality testing laboratories worldwide. Correct interpretation of the results of these multiplex PCR reactions is, therefore, now the challenge. Via educational workshops, publications, and a website-based support system, the EuroClonality group is actively contributing to optimal use and interpretation of these assays. One of the major issues in correct interpretation of clonality testing results appears to be the occurrence of multiple clonal PCR products. This is especially true for the IGK and TCRB targets due to the intrinsic complexity of the configuration of these two loci. Here, we address the issue of multiple clonal products, evaluate situations in which multiple rearrangements are generated in the IGK and TCRB loci, and discuss the interpretation of multiple products in the context of clonality assessment diagnostics.

\section{Multiple rearrangements can result in multiple clonal products}

Both B and T lymphocytes undergo several stages of differentiation. For B lymphocytes, the initial differentiation process takes place in the bone marrow, whereas early $\mathrm{T}$ lymphocyte differentiation is in the thymus. A common feature of both differentiation pathways is the fact that the precursor B cells and precursor T cells (also called thymocytes) undergo hierarchical gene rearrangements in their Ig and TCR loci, respectively $[2,13]$. B cell precursors start rearranging the $I G H$ locus with an initial D-J gene rearrangement, followed by coupling of a $\mathrm{V}$ gene to the $\mathrm{D}-\mathrm{J}$ recombination; following evaluation of the expressed $\mathrm{IgH}$ chain in a preB cell receptor (preBCR) complex, the next step is to create a proper Ig light chain. To this end, the $I G K$ locus first starts to rearrange its $\mathrm{V}$ and $\mathrm{J}$ genes. If this does not lead to a good Igk chain, the next step is to rearrange $\mathrm{V}$ and $\mathrm{J}$ genes in the $I G L$ locus in order to generate a good $\operatorname{Ig} \lambda$ chain (Fig. 1a). In an analogous way, thymocytes undergo hierarchical rearrangements in their TCR loci, starting with $\mathrm{D}-\mathrm{D}, \mathrm{D}-\mathrm{J}$, and $\mathrm{V}-\mathrm{DJ}$ recombinations in the TCRD locus, followed by $\mathrm{V}-\mathrm{J}$ rearrangements in the $T C R G$ locus. Unless this leads to a proper $\mathrm{TCR} \gamma \delta$ receptor, the thymocytes will continue to rearrange their $T C R B$ loci (initially $\mathrm{D}-\mathrm{J}$, followed by V-DJ rearrangement) and, finally, their TCRA loci (V-J recombinations) (Fig. 1b).

The mere purpose of the whole $\mathrm{V}(\mathrm{D}) \mathrm{J}$ recombination process is thus to create a unique antigen receptor (Ig or TCR molecule) that is positively selected to recognize antigen and negatively selected for showing too high affinity to autoantigens. However, V(D)J recombination is not a directed process. Rather, the coupling of $\mathrm{V}$, (D), and J genes is purely random. Moreover, during the actual coupling process, the involved $\mathrm{V}, \mathrm{D}$ and $\mathrm{J}$ genes are trimmed and nontemplated nucleotides are (randomly) inserted, which further adds to the diversity. Since a proper antigen receptor chain can only be formed if the reading frame of three nucleotides (triplet codons) is preserved, many rearrangements are unproductive (out-of-frame rearrangement or rearrangement with stop codon). This implies that for a given Ig/TCR locus, very frequently two rearrangement attempts have taken place: one on each chromosome (allele). Given that the theoretical chance for a rearrangements to be in the correct reading frame and lacking a stop codon is $25-30 \%$, this implies that biallelic Ig/TCR gene rearrangements (D-J and/or V-DJ) are thus more rule than exception in B and $\mathrm{T}$ lymphocytes.

Since leukemias and lymphomas are the malignant counterparts of normal lymphocytes, it can be appreciated that the tumor clones that derive from a single transformed lymphocyte mostly contain biallelic rearrangements as well. Hence, in PCR-based clonality testing, the combination of two $\mathrm{V}-(\mathrm{D}) \mathrm{J}$ rearrangement products or one incomplete D-J product and a complete $\mathrm{V}-(\mathrm{D}) \mathrm{J}$ product is frequently seen. Even though biallelic rearrangements are thus the most likely underlying biological phenomenon for having two PCR products, the presence of two different clones could also be compatible with multiple products. Indeed, the presence of two parallel clones has been described in leukemia and lymphoma with a frequency of $\sim 5 \%$ of cases [9]. That notwithstanding, biallelic rearrangements in lymphoma are often a more logical explanation than biclonality, unless additional evidence is available on the existence of two phenotypically distinct cell populations from either immunohistochemistry or flowcytometry.

Detection of up to two rearrangements per $\mathrm{Ig} / \mathrm{TCR}$ locus can thus be readily explained by mono- or biallelic rearrangements. However, if three or more PCR products are found, other explanations have to be considered including the existence of two clones (biclonality) or even multiple clones (oligoclonality). In order to distinguish between (biallelic) monoclonality versus biclonality versus multiple clones/oligoclonality, a careful evaluation of the number of distinct PCR products per locus is required (Table 1). However, it may occasionally be difficult to determine which PCR products truly reflect clonal rearrangements. It is, therefore, strongly recommend to always run clonality assays in duplicate. Results from duplicate analyses will disclose the reproducibility of the PCR products in terms of amplicon size and signal intensity, which facilitates proper interpretation of the number of true clonal products (one, two or more). Notably, in case of a limited number of cells (so-called paucicellular samples), often seemingly clear clonal PCR products are detected albeit with nonreproducible amplicon sizes. This is sometimes referred to as pseudoclonality, which is defined as the detection of nonreproducible clonal PCR products due to 
A

bone marrow<smiles>C1=C=C=C=C=C=C=C=C=1</smiles>

$\mathrm{HSC}$<smiles>CI1C=C=C=CC=CC=C=C1</smiles>

pro-B

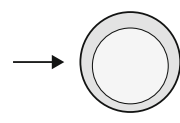

pre-B-I

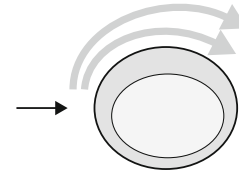

pre-B-II large<smiles>Cc1ccccc1</smiles>

pre-B-II small

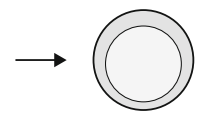

immature

B

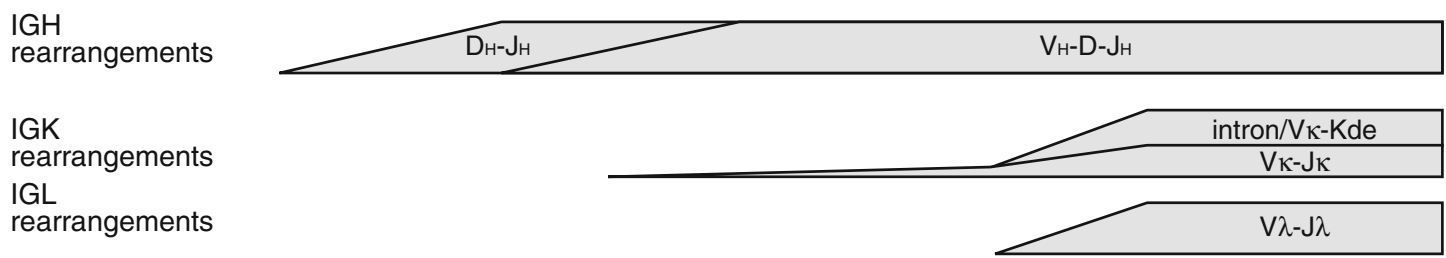

B

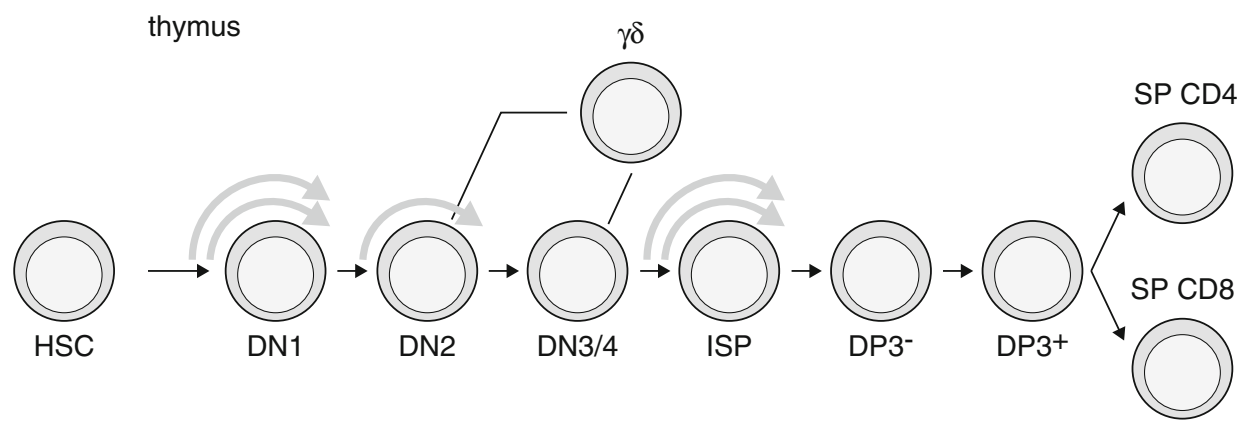

$\underset{\text { TCRD/A }}{\text { rearrangements }}[$

TCRG

rearrangements

TCRB

rearrangements

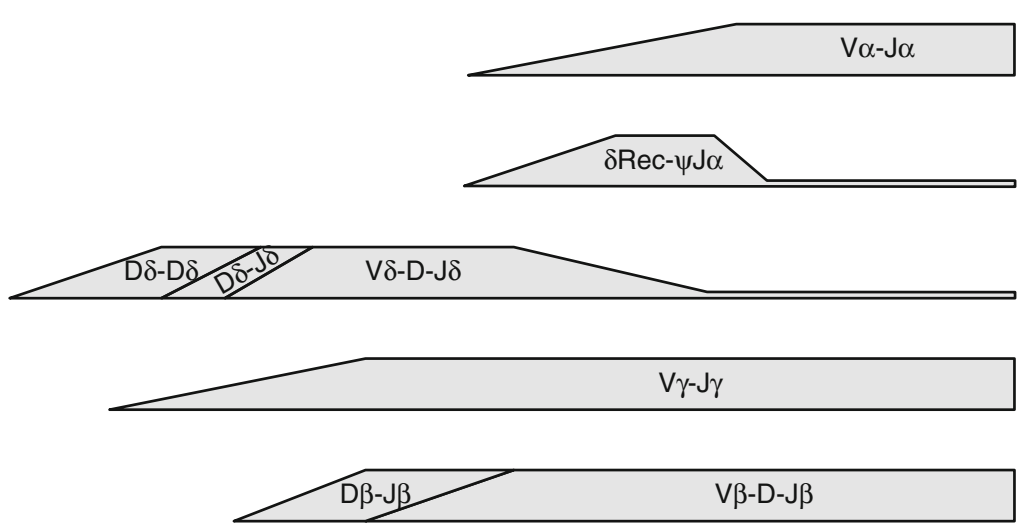

Fig. 1 Gene rearrangements during human lymphoid differentiation. a Hierarchy of Ig gene rearrangements during human precursor B cell differentiation in the bone marrow. b Hierarchy of TCR gene rearrangements during human precursor T cell differentiation in the thymus. HSC hematopoietic stem cell, $D N$ double negative thymocyte, $D P$ double positive thymocyte, ISP immature single positive thymocyte, $S P$ single positive thymocyte. a was adapted from Van Zelm et al. [13]. b was adapted from Dik et al. [2] selective amplification of low amount of template (Table 1). When there is a broad and diverse repertoire, which in fact reflects many different lymphocytes (clones), the term polyclonality is used. Evaluation of two different Ig or TCR targets (IGH plus IGK or TCRG plus TCRB) might sometimes shed light on interpretation of the number of clones present in the lesion. It should be noted, however, that the IGK and TCRB loci are a bit exceptional. Due to their specific configuration, $>1$ rearrangement can be present on the same chromosome/ allele, and hence, three or even four PCR products can easily be compatible with one clone (Table 1). The complexity of the IGK and TCRB loci and the expected type and number of PCR products will be addressed in the next sections in more detail.

\section{Multiple rearrangements in the $I G K$ locus}

When during its differentiation a precursor $\mathrm{B}$ cell is not successful in creating a productive $I G K$ rearrangement, 
Table 1 Spectrum of clonality

\begin{tabular}{lll}
\hline Term & Interpretation & Expected result \\
\hline Monoclonality (monoallellelic) & Monoclonal cell population (with or without background) & 1 clonal rearrangement per locus ${ }^{\mathrm{a}}$ \\
Monoclonality (biallelic) & Monoclonal cell population (with or without background) & 2 clonal rearrangements per locus $^{\mathrm{a}}$ \\
Biclonality & Biclonal cell population (with or without background) & $2-4$ clonal rearrangements per locus $^{\mathrm{a}}$ \\
Oligoclonality & Multiple clones & $>4$ rearrangements per locus $^{\mathrm{a}}$ \\
Polyclonality & Diverse repertoire & Multiple rearrangements \\
Pseudoclonality & Paucicellular samples & Nonreproducible clonal rearrangements \\
& & (due to selective amplification)
\end{tabular}

${ }^{a}$ It should be noted that for IGK and TCRB, these numbers are higher (up to twice as high) as compared to other Ig/TCR loci (see text for further explanation and details)

further recombination between one of the upstream Vk genes and one of the downstream $\mathrm{J}_{\mathrm{K}}$ genes might occur. In theory, such ongoing recombination can be repeated as long as upstream VK genes and downstream $J_{K}$ genes are still present on that allele. Alternatively, the second $I G K$ allele will undergo one or more $\mathrm{VK}-\mathrm{JK}$ recombinations in an attempt to make a productive $I G K$ rearrangement (in-frame, no stop codon). If all options fail, the precursor B cell will switch to recombination of the $I G L$ locus. Prior to initiation of $I G L$ recombination, however, a completely different type of $I G K$ recombination occurs. This is due to the presence of additional elements in the IGK locus that can be involved in recombination (reviewed in Langerak and Van Dongen [5]) (Fig. 2a). One of these is the so-called Kappa deleting element (Kde), which is located $24 \mathrm{~kb}$ downstream of the $\mathrm{CK}$ region. This Kde can recombine to i) any of the $\mathrm{VK}$ genes upstream of the unproductive $\mathrm{V} K-\mathrm{J} K_{K}$ exon (resulting in a Vk-Kde rearrangement) or ii) the other nonclassical $I G K$ rearrangeable sequence in the intron (intron RSS) between the $\mathrm{J}_{K}$ genes and the $\mathrm{C} K$ region (leading to an intron-Kde rearrangement) (Fig. 2b). The effect of both types of rearrangements is a deletion of the $\mathrm{CK}_{K}$ region on the involved allele as well as of the iEK and $3^{\prime} \mathrm{EK}$ enhancer regions that normally control expression of the $I G K$ locus in cis. The net effect of these recombinations is thus a complete functional inactivation of the involved $I G K$ allele. In the case of a $\mathrm{VK}-\mathrm{Kde}$ rearrangement, the preexisting $\mathrm{VK}_{\mathrm{K}} \mathrm{JK}$ recombination is thereby removed (Fig. 2b). However, in the other scenario in which an intron-Kde rearrangement is employed to inactivate the $I G K$ locus, the prior $\mathrm{VK}-\mathrm{JK}_{\mathrm{K}}$ recombination will be preserved. As a consequence, two different $I G K$ rearrangements now reside on the same allele: a $\mathrm{VK}_{\kappa}-\mathrm{JK}_{\mathrm{K}}$ rearrangement plus an intron-Kde rearrangement (Fig. 2b).

Depending on the exact configuration of its two IGK alleles, up to four rearrangements can thus be present in one cell (Table 2). This phenomenon has major implications for interpretation of multiple PCR products in IGK clonality testing. The BIOMED-2 multiplex $I G K$ assay consists of two reaction mixtures, one targeting the classical $\mathrm{VK}_{\mathrm{K}}-\mathrm{JK}_{\mathrm{K}}$ rearrangements (tube A) and the other targeting the Kde rearrangements (tube B). Both assays are very informative and have proven their clear complementary value in clonality testing [3]. Particularly, the Kde assay has an enormous advantage because it targets rearrangements that are free of somatic hypermutations, thus reducing the rate of false negativity. However, when applying both $I G K$ assays ( $\mathrm{VK}-\mathrm{JK}_{\mathrm{K}}$ rearrangements plus Kde rearrangements) cautious interpretation is thus warranted due to the biological complexity of the IGK locus. In fact, per assay, a total of two rearrangements can be detected per clone (similar to other Ig/TCR loci), but for both $I G K$ multiplex assays, together this can mount to four distinct PCR products in a single B cell clone (Fig. 3; Table 2). A practical approach when dealing with complex $I G K$ patterns from multiplex tubes A and $\mathrm{B}$ would be to interpret the pattern of a given case along with the configurations as mentioned in Table 2 . This will help to evaluate if and how the clonal products could belong to the same clone. As IGH patterns will often be available as well, this will almost always help to confirm or

Fig. 2 Multiple rearrangements in the human $I G K$ locus. a Overview of the human IGK locus on chromosome band 2p11.2. Rearrangeable VK genes are indicated in dark grey (productive genes) or light gray (unproductive genes). The cluster with inverted VK genes (designated with D) is located approximately $800 \mathrm{~kb}$ upstream of the noninverted proximal Vk gene cluster. Adapted from ImMunoGeneTics database (www.imgt.org). b A schematic representation of consecutive rearrangements in the human $I G K$ locus. Following an initial $\mathrm{VK}-\mathrm{JK}_{\mathrm{K}}$ rearrangement, additional rearrangements can occur that inactivate the IGK locus by removing the $\mathrm{CK}$ region and the enhancers (iEK and $\left.3^{\prime} \mathrm{EK}\right)$. These inactivating rearrangements involve the Kde sequence that can recombine to one of the $V \kappa$ genes ( $V K-K d e$ rearrangement), thereby deleting the preexisting $\mathrm{V} K_{\kappa}-\mathrm{J}_{\mathrm{K}}$ rearrangement. Alternatively, Kde recombines to an isolated recombination signal sequence (RSS) in the $\mathrm{J}_{K}-\mathrm{CK}_{K}$ intron; in that situation, the earlier $\mathrm{VK}_{K}-\mathrm{JK}_{K}$ and intron-Kde rearrangements are both present on the same allele. $\mathbf{c}$ The $\mathrm{V} \kappa$ genes are organized in a proximal cluster and a distal cluster, the latter showing an inverted orientation. Whereas recombination between a Vk proximal gene and a $\mathrm{JK}$ gene follows the normal rearrangement process with deletion of the intermediate region, recombination between a $\mathrm{JK}_{K}$ gene and a VK distal gene can only occur through an inversional rearrangement without loss of genomic DNA. Ongoing VK-JK recombination involving a VK distal gene will thus result in two different $\mathrm{V}_{\kappa}-\mathrm{J}_{\kappa}$ rearrangements being present on the same allele 
A $25 \mathrm{~kb}$

tel $\rightarrow$
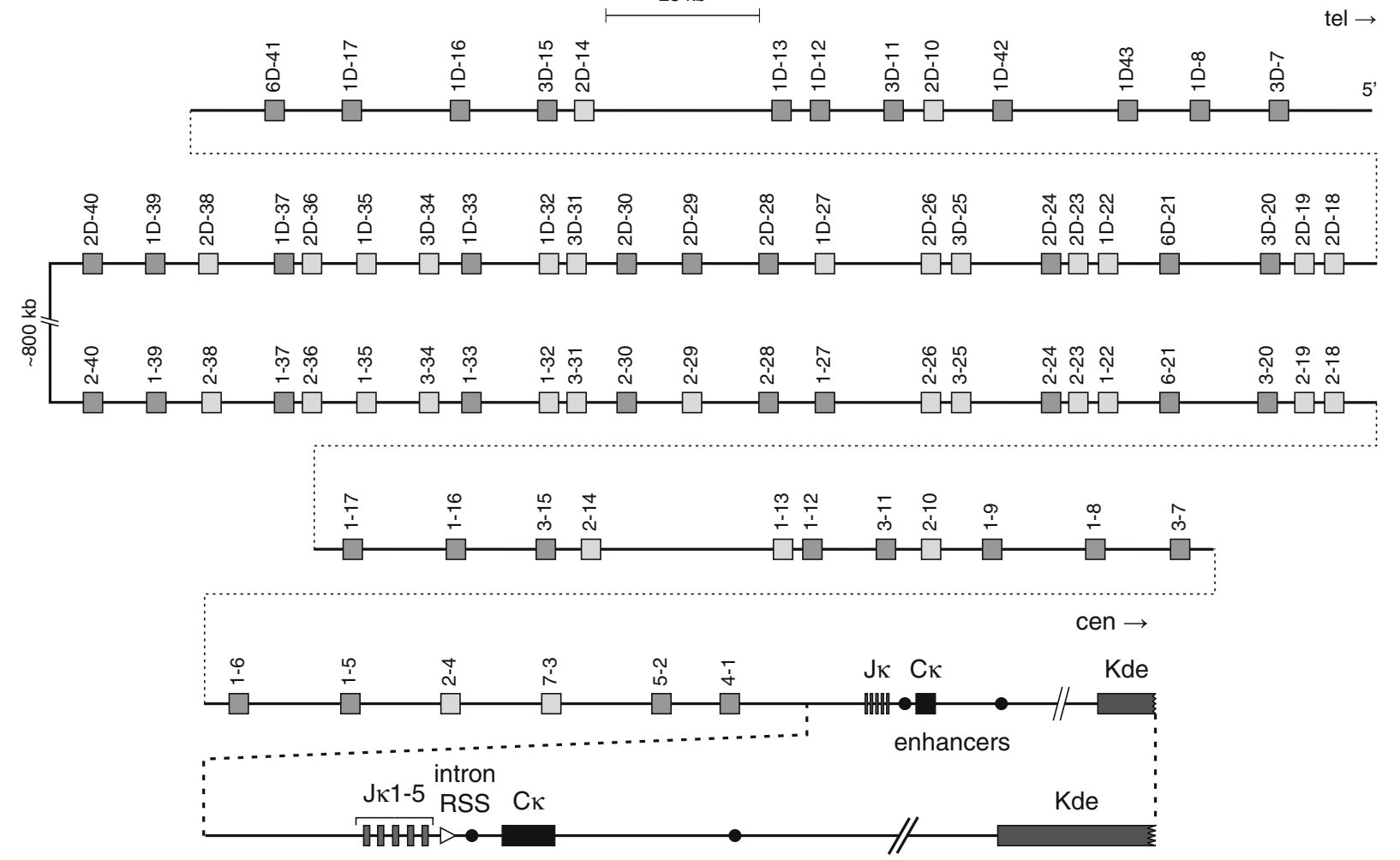

B
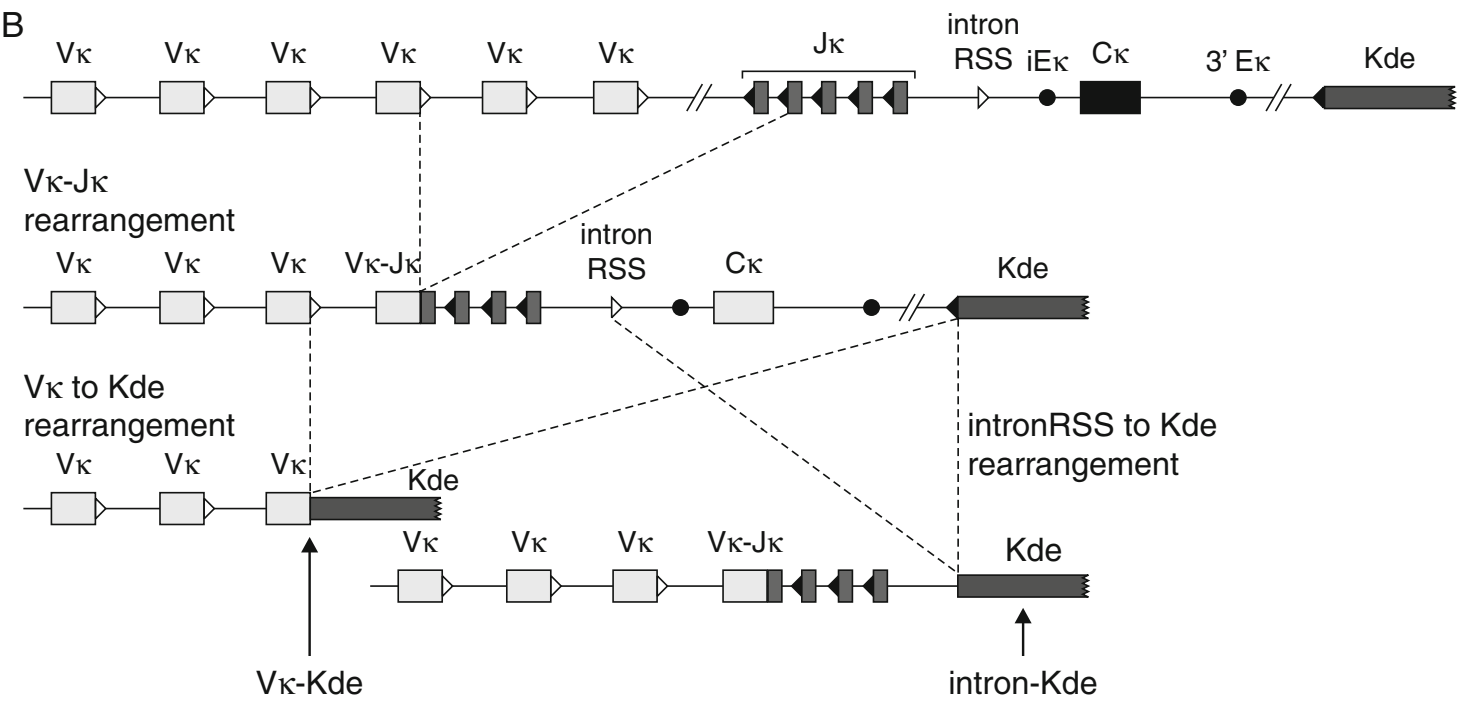

C

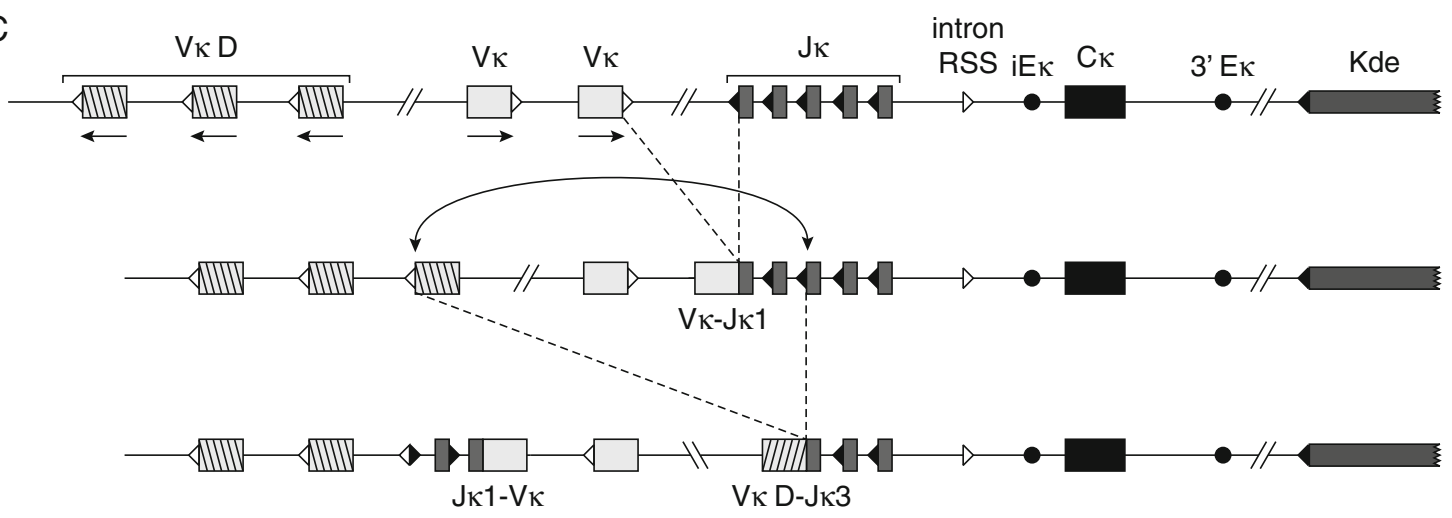


Table 2 Summary of different IGK rearrangement configurations that are compatible with a single clone

\begin{tabular}{|c|c|c|c|}
\hline \multirow[t]{2}{*}{ IGK configuration } & \multicolumn{3}{|c|}{ Number of rearrangements detectable } \\
\hline & 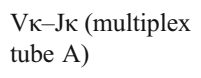 & $\begin{array}{l}\text { Intron/Vk-Kde } \\
\text { (multiplex tube B) }\end{array}$ & Total \\
\hline $\mathrm{G} / \mathrm{G}$ & 0 & 0 & 0 \\
\hline $\mathrm{G} / \mathrm{V}-\mathrm{J}^{\mathrm{a}}$ & 1 & 0 & 1 \\
\hline G/V-Kde & 0 & 1 & 1 \\
\hline $\mathrm{G} / \mathrm{V}-\mathrm{J}^{\mathrm{a}}+$ intr-Kde & 1 & 1 & 2 \\
\hline $\mathrm{V}-\mathrm{J}^{\mathrm{a}} / \mathrm{V}-\mathrm{J}^{\mathrm{a}}$ & 2 & 0 & 2 \\
\hline $\mathrm{V}-\mathrm{J}^{\mathrm{a}} / \mathrm{V}-\mathrm{Kde}$ & 1 & 1 & 2 \\
\hline V-Kde/V-Kde & 0 & 2 & 2 \\
\hline $\mathrm{V}-\mathrm{J}^{\mathrm{a}}+$ intr-Kde/V-Kde & 1 & 2 & 3 \\
\hline $\mathrm{V}-\mathrm{J}^{\mathrm{a}}+$ intr-Kde $/ \mathrm{V}-\mathrm{J}^{\mathrm{a}}+$ intr-Kde & 2 & 2 & 4 \\
\hline
\end{tabular}

${ }^{\mathrm{a}}$ Theoretically, more than a single $\mathrm{V}_{\mathrm{K}}-\mathrm{J}_{\mathrm{K}}$ rearrangement might occur on one allele, if successive inversional $\mathrm{VK}_{\mathrm{K}}-\mathrm{JK}_{\mathrm{K}}$ rearrangements occur that involve the upstream/distal, inverted VK gene cluster (see text for further details). Such multiple $V_{K}-J_{K}$ rearrangements are not included in this table

exclude the monoclonal character of the suspect B cell population. Only in ambiguous cases might sequencing of the products be necessary to solve interpretation.
For reasons of completeness, it is good to mention that yet other rearrangements involving the intron RSS element can occur in the human IGK locus [4]. However, as these so-called $\mathrm{J}$-intron rearrangements are quite rare and not detectable with the $I G K$ multiplex clonality assays, they are beyond the scope of this paper and thus not further discussed here.

One other complicating aspect of the human IGK locus is worth mentioning here as it may influence interpretation of multiple PCR products. Contrary to other Ig/TCR loci, the $V \kappa$ genes are organized in two different clusters: a proximal cluster just upstream of the $J_{K}$ genes and a distal cluster further upstream (Fig. 2a). This 3' distal cluster has most probably arisen by duplication during evolution. The involved VK genes in this distal cluster show an inverted orientation, implying that an inversional rearrangement is required to form a $\mathrm{V}-\mathrm{J}$ recombination. As during an inversional rearrangement no DNA is removed from the genome, this $V_{K}-J_{K}$ recombination will be preserved upon a second inversional $V_{K}-J_{K}$ rearrangement (Fig. 2c). Consequently, theoretically, two or more $\mathrm{VK}_{\mathrm{K}}-\mathrm{J}_{\mathrm{K}}$ rearrangements would be detectable on the same allele if ongoing recombinations occur multiple times in an attempt to obtain a productive $I G K$ allele. This inversional rearrangement process would imply that even

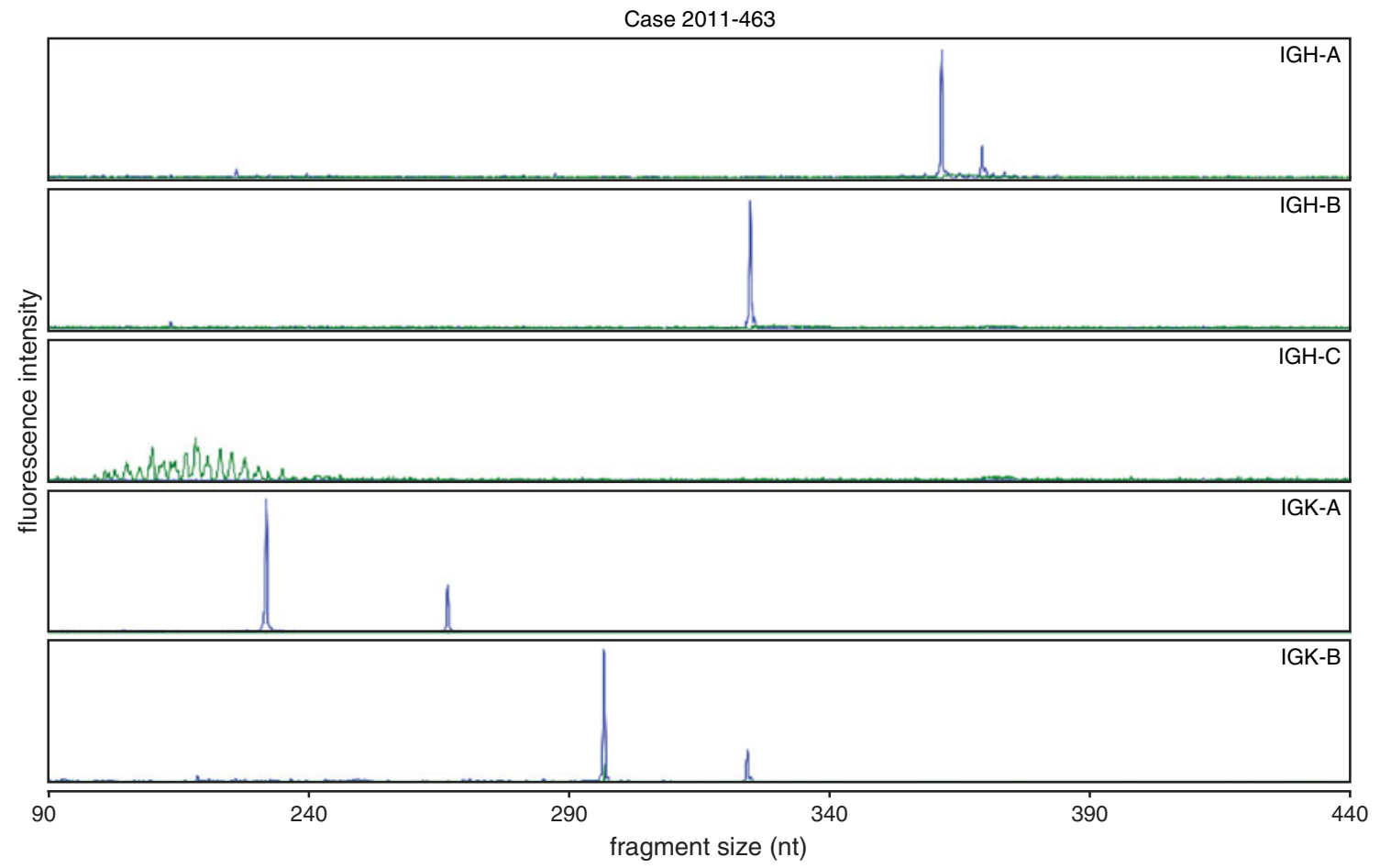

Fig. 3 Example of a case with multiple $I G K$ products belonging to one clone. In case 2011-463, an aberrant leukemic B cell population is diagnosed. GeneScan analysis of $I G K$ tube A shows two different clonal V-J products (149 and $197 \mathrm{nt}$, respectively), whereas two additional clonal Kde products are seen upon analysis of $I G K$ tube $\mathrm{B}$ (239 and $278 \mathrm{nt}$ products). Based on the amplicon sizes, the most logical explanation of these $I G K$ patterns is a $\mathrm{VK}_{\mathrm{K}}-\mathrm{J} \mathrm{K}$ product (149 nt) on one allele, together with an intron-Kde rearrangement on the same allele (278-nt product), whereas the second allele contains a VK-Kde rearrangement (239-nt product). The 197-nt $V_{K}-J_{K}$ product most probably results from known cross-priming of the $V_{k} 3$ primer to the true $\mathrm{VK}-\mathrm{JK}_{\mathrm{K}}$ rearranged product. Thus, the $I G K$ pattern is still compatible with a single $\mathrm{B}$ cell clone (see also Table 2), which is confirmed by the GeneScan analysis results of $I G H$ tubes A (330/340 nt), B (278 nt), and C (polyclonality) 


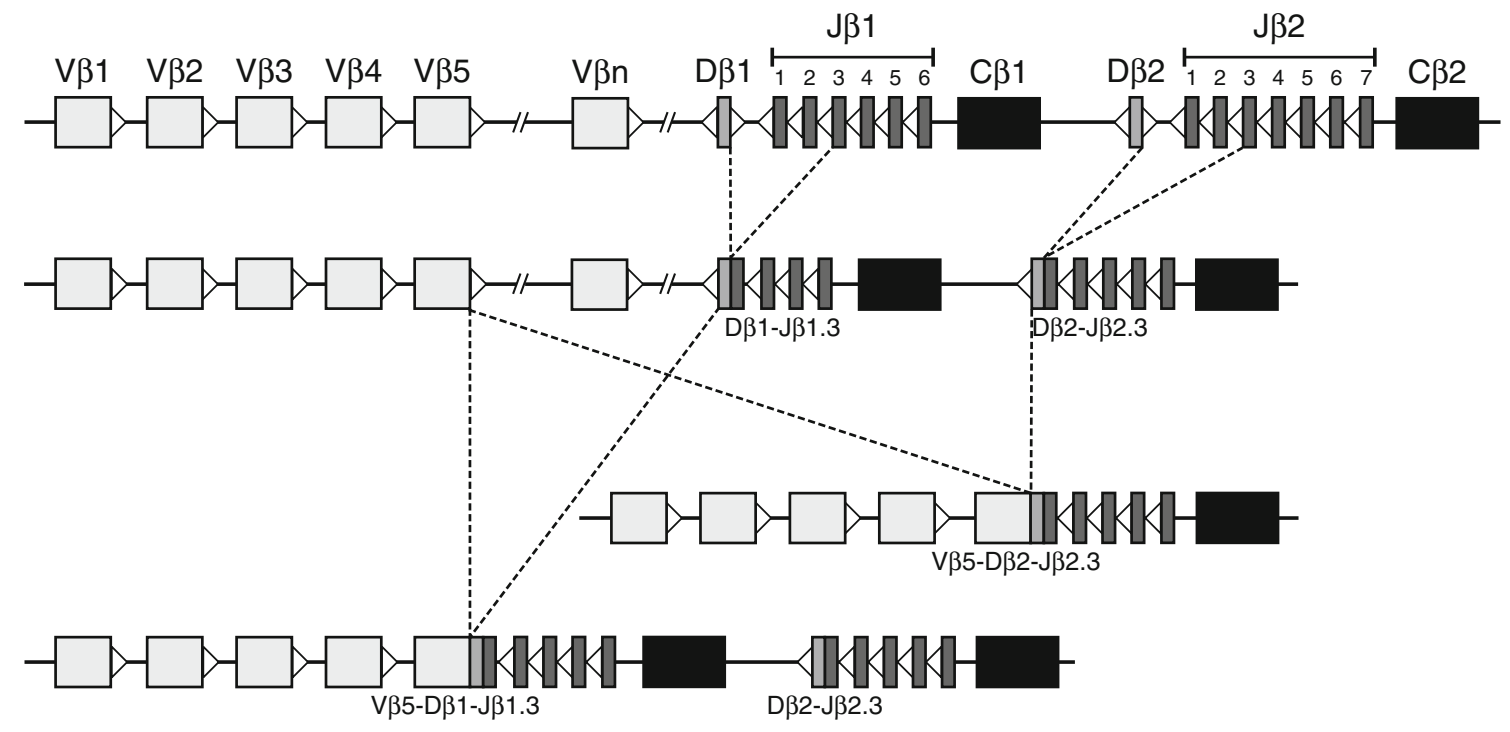

Fig. 4 Multiple rearrangements in the human TCRB locus. The human $T C R B$ locus consists of two $\mathrm{D} \beta-\mathrm{J} \beta$ clusters. As a result, two independent $\mathrm{D} \beta-\mathrm{J} \beta$ rearrangements (one involving the $\beta 1$ region, the other involving the $\beta 2$ region) can be present on the same allele. In the

more $\mathrm{V} K-\mathrm{J}_{K}$ PCR products belonging to one clone might be detectable in a given case. It is quite hard to address this phenomenon experimentally or to estimate the extent of its occurrence, but it is something that should be considered when interpreting $I G K$ clonality testing data.

Finally, some of the VK primers in the multiplex assay are known to show some level of cross-reactivity to particular genes of other $V_{k}$ families. As the bindings sites for the different $\mathrm{VK}$ family primers are not all clustered in the same area, this might sometimes give an additional (weak) PCR product next to the correct $\mathrm{V} K-\mathrm{J}_{K}$ PCR product. Collectively, this means that there is no direct relationship between the number of clonal $I G K$ PCR products and the number of $\mathrm{B}$ cell clones, and that caution is needed in interpreting $I G K$ clonality testing results.

\section{Multiple rearrangements in the $T C R B$ locus}

Notably, all Ig and TCR loci roughly have a similar genomic configuration, with a cluster of $\mathrm{V}$ genes, a cluster of $\mathrm{D}$ genes (at least for some loci), and a cluster of J genes. However, the configuration of the TCRB locus is slightly different in the sense that the two $\mathrm{D} \beta$ genes are not clustered but rather dispersed. Moreover, each of these $\mathrm{D} \beta$ genes comes with its own set of $\mathrm{J} \beta$ genes (Fig. 4). This configuration of two $\mathrm{D} \beta-\mathrm{J} \beta$ clusters has probably arisen through duplication during evolution and has clear implications for rearrangement detection.

If during differentiation a thymocyte has not productively rearranged its $T C R D$ and $T C R G$ genes to form a functional $\mathrm{TCR} \gamma \delta$ receptor, recombination will start in the TCRB locus second phase, a V $\beta$ gene can rearrange to either one of the $D \beta-J \beta$ joints. Depending on the $\mathrm{D} \beta-\mathrm{J} \beta$ joint that is targeted, this will create multiple rearrangements $(\mathrm{V} \beta-\mathrm{D} \beta-\mathrm{J} \beta 1$ plus $\mathrm{D} \beta 2-\mathrm{J} \beta 2)$ or just a single rearrangement $(\mathrm{V} \beta-\mathrm{D} \beta-\mathrm{J} \beta 2)$ on that allele

(Fig. 1b). Normally, as a first step in $T C R B$ recombination one of the two $D \beta$ genes will be coupled to one of the $J \beta$ genes. As a direct consequence of the specific TCRB configuration with two separated $\mathrm{D} \beta-\mathrm{J} \beta$ regions $(\beta 1$ and $\beta 2$ areas), two different $\mathrm{D} \beta-\mathrm{J} \beta$ rearrangements might be formed on the same allele. If during further differentiation the thymocyte continues to rearrange its TCRB locus, one of these two $\mathrm{D} \beta-\mathrm{J} \beta$ recombinations will be completed to a $\mathrm{V} \beta-\mathrm{D} \beta-\mathrm{J} \beta$ rearrangement. In case this $\mathrm{V} \beta-\mathrm{D} \beta-\mathrm{J} \beta$ rearrangement involves the prior $\mathrm{D} \beta 2-\mathrm{J} \beta 2$ recombination, the entire intergenic region including the already formed $\mathrm{D} \beta 1-$ $\mathrm{J} \beta 1$ recombination will be removed on the circular excision product. Conversely, if the $\mathrm{V} \beta-\mathrm{D} \beta-\mathrm{J} \beta$ rearrangement

Table 3 Summary of different TCRB rearrangement configurations that are compatible with a single clone

\begin{tabular}{|c|c|c|c|}
\hline \multirow[t]{2}{*}{ IGK configuration } & \multicolumn{3}{|c|}{ Number of rearrangements detectable } \\
\hline & $\begin{array}{l}\mathrm{V} \beta-\mathrm{J} \beta \text { (multiplex } \\
\text { tube } \mathrm{A} / \mathrm{B} \text { ) }\end{array}$ & $\begin{array}{l}\mathrm{D} \beta-\mathrm{J} \beta \text { (multiplex } \\
\text { tube } \mathrm{C} \text { ) }\end{array}$ & Total \\
\hline $\mathrm{G} / \mathrm{G}$ & 0 & 0 & 0 \\
\hline $\mathrm{G} / \mathrm{D}-\mathrm{J}_{1}$ or 2 & 0 & 1 & 1 \\
\hline $\mathrm{G} / \mathrm{V}-\mathrm{J}_{1}$ or 2 & 1 & 0 & 1 \\
\hline $\mathrm{G} / \mathrm{D}-\mathrm{J}_{1}+\mathrm{D}-\mathrm{J}_{2}$ & 0 & 2 & 2 \\
\hline $\mathrm{G} / \mathrm{V}-\mathrm{J}_{1}+\mathrm{D}-\mathrm{J}_{2}$ & 1 & 1 & 2 \\
\hline $\mathrm{V}-\mathrm{J}_{1}$ or $2 / \mathrm{V}-\mathrm{J}_{1}$ or 2 & 2 & 0 & 2 \\
\hline $\mathrm{V}-\mathrm{J}_{1 \text { or } 2} / \mathrm{V}-\mathrm{J}_{1}+\mathrm{D}-\mathrm{J}_{2}$ & 2 & 1 & 3 \\
\hline $\mathrm{D}-\mathrm{J}_{1}+\mathrm{D}-\mathrm{J}_{2} / \mathrm{D}-\mathrm{J}_{1}+\mathrm{D}-\mathrm{J}_{2}$ & 0 & 4 & 4 \\
\hline $\mathrm{V}-\mathrm{J}_{1}+\mathrm{D}-\mathrm{J}_{2} / \mathrm{D}-\mathrm{J}_{1}+\mathrm{D}-\mathrm{J}_{2}$ & 1 & 3 & 4 \\
\hline $\mathrm{V}-\mathrm{J}_{1}+\mathrm{D}-\mathrm{J}_{2} / \mathrm{V}-\mathrm{J}_{1}+\mathrm{D}-\mathrm{J}_{2}$ & 2 & 2 & 4 \\
\hline
\end{tabular}


involves the prior $\mathrm{D} \beta 1-\mathrm{J} \beta 1$ recombination, the more downstream located $\mathrm{D} \beta 2-\mathrm{J} \beta 2$ recombination will now be preserved on the same allele (Fig. 4). Hence, based on the exact type of rearrangements that occur on the two TCRB alleles, multiple PCR products might be amplified from one clone. When evaluating only the two complementary $V \beta-J \beta$ multiplex PCR assays (BIOMED-2 tubes A and B), the number of PCR products (of correct size) is limited to two. However, if also $\mathrm{D} \beta-\mathrm{J} \beta$ rearrangements (BIOMED-2 TCRB tube $\mathrm{C}$ ) are evaluated, the number of distinct PCR products compatible with one clone could mount to four (Table 3).

Apart from the multiple rearrangements on one allele, another phenomenon might complicate $T C R B$ analysis with respect to multiple PCR products. Both $\mathrm{V} \beta-\mathrm{J} \beta$ and $\mathrm{D} \beta-\mathrm{J} \beta$ rearrangements could give rise to the occurrence of additional PCR products of extended size. This is to be explained by the relatively small intergenic $J \beta$ gene distances of sometimes just $100-150 \mathrm{bp}$. As both TCRB multiplex PCR mixtures consist of $J \beta$ gene-specific primers, occasionally this would allow additional amplification of a particular $\mathrm{V} \beta-\mathrm{J} \beta / \mathrm{D} \beta-\mathrm{J} \beta$ rearrangement from the $\mathrm{J} \beta$ gene immediately downstream of the $\mathrm{J} \beta$ gene that is involved in the actual rearrangement $[7,8]$. When the primer for the downstream $J \beta$ gene is present in the same mixture, this will give rise to double products (of distinct size) in the same PCR reaction (Fig. 5). Even more subtle is the situation that the $\mathrm{V} \beta-\mathrm{J} \beta$ rearrangement gives rise to an amplicon of the correct size in the one reaction (amplified with the true $\mathrm{J} \beta$ primer) and to an extended amplicon in the other PCR reaction (amplified with a primer for the downstream J $\beta$ gene). The phenomenon of extended PCR products (including $T C R B$ ) is discussed in much more detail in the article by Rothberg et al. (this issue of the journal).
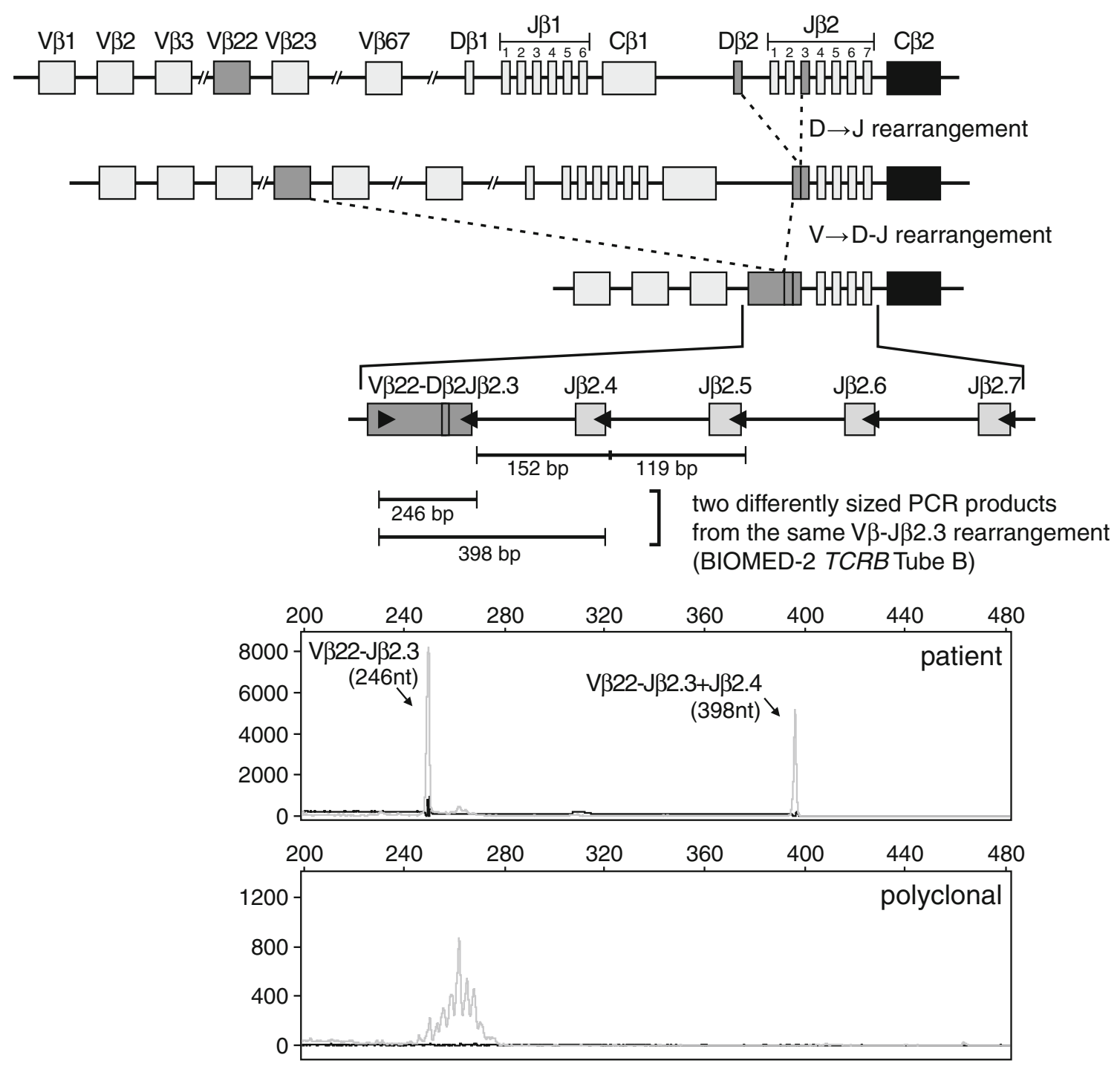

Fig. 5 Extended PCR products in the human TCRB locus. Because of the close proximity of the $\mathrm{J} \beta$ genes, extended PCR products can be generated due to priming from a downstream $\mathrm{J} \beta$ gene. In the example, the $\mathrm{V} \beta 22-\mathrm{J} \beta 2.3$ rearrangement is detected as a $246-\mathrm{nt}$ product in GeneScan analysis, while an extended 398-nt product is detected that results from priming at the $\mathrm{J} \beta 2.4$ gene (figure from: [7]) 
Similar to what has been discussed for complex $I G K$ patterns, the presence of multiple TCRB products should also be interpreted in comparison to the possible TCRB configurations (Table 3), while taking into account the phenomenon of extended TCRB products as well.

\section{Concluding remarks on interpretation of multiple clonal products}

Knowledge on the immunobiological phenomena leading to multiple clonal Ig or TCR products is a key issue for correct interpretation of clonality testing results. Although an obvious relation exists between the number of clonal products for a given $\mathrm{Ig} / \mathrm{TCR}$ locus and the number of $\mathrm{B} / \mathrm{T}$ cell clones (spectrum of monoclonality-biclonality-oligoclonalitypolyclonality), the situation is not always that straightforward. First, the presence of two different PCR products could reflect biclonality but can often more easily be attributed to the occurrence of biallelic rearrangements in a single clone. Second, due to the specific configuration of the IGK and $T C R B$ loci, multiple rearrangements can occur on one allele resulting in the possibility that up to four PCR products could be compatible with a single clone. Finally, when $>2$ clonal Ig/ TCR products ( $>4$ for $I G K$ and TCRB) are detectable, this could reflect biclonality, oligoclonality, or even pseudoclonality. It is not always easy to distinguish between those options but the use of duplicates will be helpful to determine reproducibility and relevance of the detected clonal PCR products. In conclusion, straightforward interpretation of clonality testing results can be hampered by the occurrence of multiple clonal products. Only careful consideration of immunobiological and technical explanations will prevent incorrect interpretation in such cases.

Acknowledgments We thank our colleagues from the BIOMED-2/ EuroClonality network for fruitful discussions and the members of the clonality lab, Dept. of Immunology, Erasmus MC (Ingrid Wolvers, Ellen van Gastel, Brenda Verhaaf, Dennis Tielemans, Joyce Vermeulen, and Ashley van der Spek), for their continuous support and valuable contributions to this study. We acknowledge Sandra de Bruin-Versteeg for help in preparing figures.

\section{References}

1. Brüggemann M, White H, Gaulard P, Garcia-Sanz R, Gameiro P, Oeschger S, Jasani B, Ott M, Delsol G, Orfao A, Tiemann M, Herbst H, Langerak AW, Spaargaren M, Moreau E, Groenen PJTA, Sambade S, Foroni L, Carter GI, Hummel M, Bastard C, Davi F, Delfau MH, Kneba M, Van Dongen JJM, Macintyre EA, Molina TJ (2007) Powerful strategy for PCR-based clonality assessment in T-cell malignancies. Report of the BIOMED-2 Concerted Action BHM4-CT98-3936. Leukemia 21:215-221
2. Dik WA, Pike-Overzet K, Weerkamp F, De Ridder D, De Haas EF, Baert MRM, Van der Spek P, Koster EEL, Reinders MJT, Van Dongen JJM, Langerak AW, Staal FJT (2005) New insights on human T-cell development by quantitative T-cell receptor gene rearrangement studies and gene expression profiling. J Exp Med 201:1715-1723

3. Evans PA, Pott Ch, Groenen PJ, Salles G, Davi F, Berger F, Garcia JF, van Krieken JH, Pals S, Kluin P, Schuuring E, Spaargaren M, Boone E, González D, Martinez B, Villuendas R, Gameiro P, Diss TC, Mills K, Morgan GJ, Carter GI, Milner BJ, Pearson D, Hummel M, Jung W, Ott M, Canioni D, Beldjord K, Bastard C, Delfau-Larue MH, van Dongen JJM, Molina TJ, Cabeçadas J (2007) Significantly improved PCR-based clonality testing in B-cell malignancies by use of multiple immunoglobulin gene targets. Report of the BIOMED-2 Concerted Action BHM4-CT98-3936. Leukemia 21:207-214

4. Langerak AW, Nadel B, De Torbal A, Wolvers-Tettero ILM, Van Gastel-Mol EJ, Verhaaf B, Jaeger U, Van Dongen JJM (2004) Unraveling the consecutive recombination events in the human immunoglobulin kappa (IGK) locus. J Immunol 173:3878-3888

5. Langerak AW, Van Dongen JJM (2006) Recombination in the human IGK locus. Crit Rev Immunol 26:23-42

6. Langerak AW, Molina TJ, Lavender FL, Pearson D, Flohr T, Sambade C, Schuuring E, Al Saati T, van Dongen JJ, van Krieken JH (2007) Polymerase chain reaction-based clonality testing in tissue samples with reactive lymphoproliferations: usefulness and pitfalls. A report of the BIOMED-2 Concerted Action BMH4CT98-3936. Leukemia 21:222-229

7. Langerak AW, Groenen PJTA, Van Krieken JHJM, Van Dongen JJM (2007) Ig/TCR clonality diagnostics. Exp Opin Med Diagn $1: 451-461$

8. Langerak AW (2008) Undersized, oversized? It is not one-size-fitsall in lymphoid clonality detection. Leukemia Res 32:203-204

9. Sanchez ML, Almeida J, Gonzalez D, Gonzalez M, Garcia-Marcos MA, Balanzategui A, Lopez-Berges MC, Nomdedeu J, Vallespi T, Barbon M, Martin A, de la Fuente P, Martin-Nuñez G, FernandezCalvo J, Hernandez JM, San Miguel JF, Orfao A (2003) Incidence and clinicobiologic characteristics of leukemic B-cell chronic lymphoproliferative disorders with more than one B-cell clone. Blood 102:2994-3002

10. Van Dongen JJM (1987) Analysis of immunoglobulin genes and T cell receptor genes as a diagnostic tool for the detection of lymphoid malignancies. Neth J Med 31:201-209

11. Van Dongen JJ, Hooijkaas H, Michiels JJ, Grosveld G, de Klein A, van der Kwast TH, Prins ME, Abels J, Hagemeijer A (1984) Richter's syndrome with different immunoglobulin light chains and different heavy chain gene rearrangements. Blood 64:571-575

12. Van Dongen JJM, Langerak AW, Brüggemann M, Evans PA, Hummel M, Lavender L, Delabesse E, Davi F, Schuuring E, Garcia Sanz R, Van Krieken JHJM, Droese J, Gonzalez D, Bastard C, Spaargaren M, San Miguel JF, Parreira A, Smith JF, Morgan G, Kneba M, Macintyre EA (2003) Design and standardization of PCR primers and protocols for detection of clonal immunoglobulin and T-cell receptor gene rearrangements in suspect lymphoproliferations. Report of the BIOMED-2 Concerted Action BMH4-CT98-3936. Leukemia 17:2257-2317

13. Van Zelm MC, van der Burg M, de Ridder D, Barendregt BH, de Haas EF, Reinders MJ, Lankester AC, Révész T, Staal FJ, van Dongen JJ (2005) Ig gene rearrangement steps are initiated in early human precursor B cell subsets and correlate with specific transcription factor expression. J Immunol $175: 5912-5922$ 